\title{
Identification of Active Compounds of Ethanol Extract of Citrus amblycarpa leaves by Analysis of Thin-layer Chromatography and Gas Chromatography-Mass Spectrometry as Bioinsecticide Candidates for Mosquitoes
}

\author{
Kasman Kasman ${ }^{1}$, Nuning Irnawulan Ishak ${ }^{2}$, Poedji Hastutiek ${ }^{3 *}$, Endang Suprihati ${ }^{3}$, Anwar Mallongi ${ }^{4}$ \\ ${ }^{1}$ Departement of Epidemiology and Biostatistic, Faculty of Public Health, Islamic University of Kalimantan, Banjarmasin, \\ Indonesia; ${ }^{2}$ Department of Occupational Health Safety and Environmental Health, Faculty of Public Health, Islamic University \\ of Kalimantan, Banjarmasin, Indonesia; ${ }^{3}$ Department of Veterinary Parasitology, Faculty of Veterinary Medicine, Airlangga \\ University, Surabaya, Indonesia; ${ }^{4}$ Department of Environmental Health, Faculty of Public Health, Hasanuddin University, \\ Makassar, Indonesia
}

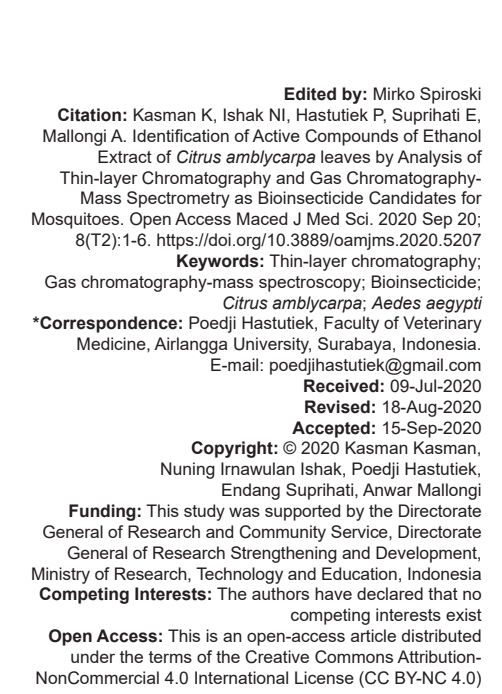

\begin{abstract}
BACKGROUND: The use of active compounds from plants becomes an alternative to control mosquitoes nowadays and in the future because they are environmentally-friendly and do not cause health problems. Citrus amblycarpa is a local orange of South Kalimantan potential as bioinsecticidal, which commonly used for controlling mosquitoes. Therefore, research needs to be done to find out the benefits of $C$. amblycarpa leaves as bioinsecticidal.

AIM: The research aimed to identify active compounds contained in the extract ethanol of $C$. amblycarpa leaves as bioinsecticidal against mosquitoes.

RESULTS: Based on thin-layer chromatography test, there were some secondary metabolite compounds found such as terpenoids/steroids, flavonoids, polyphenols, and saponins. Gas chromatography-mass spectrometry (GC-MS) test revealed that there were ten primary components of the fraction. The components were Maragenin $(18,82 \%), 1,3$-benzenedicarboxamide (12.28\%), 2,3,8-trioxocephalotaxane (10.39\%), aristolone, $2 \mathrm{H}$-cyclopropa[a] naphthalene-2-one, noruns-12-ene (7.46\%), palmitic acid, n-hexadecanoic acid (7.21\%), stigmasterol, demecolcine (7.03\%), alpha-tocopherol (5.88\%), 2,4,5-trimethylphenol, pseudocumenol (4.21\%), germacrene-D (3.45\%), and 9-octadecenoic acid (3.36\%).

CONCLUSION: These active compounds possess biological activity as bioinsecticidal. It was expected that those active compounds in C. amblycarpa leaves could be applied for controlling mosquitoes by replacing the use of resistant temephos.
\end{abstract}

\section{Introduction}

Dengue fever, both in tropical and subtropical, is a disease [1], [2] transmitted through the bites of Aedes aegypti or Aedes albopictus and caused by Dengue virus [3], [4]. South Kalimantan is a province which belongs to dengue fever endemic where 13 cities/regencies have been affected by the diseases [5]. A report from Health Agency of South Kalimantan Province showed that there are 1079 cases of dengue fever with 33 people died over 2013. In 2014, there are 363 cases of dengue fever with eight people died (incidence rate/1000 people is 1103), while in 2015 there is a significant increase in the incidence of dengue fever reaching 1.216 cases with 19 people died. The highest case occurs in Banjarmasin, Banjarbaru, and Banjar Regency [6]. The fluctuated condition of dengue fever incidence encourages a need to control A. aegypti. One of the methods to break the cycles and kill mosquitos' larvae is using insecticides [7].

The constant use of synthetic insecticides (temephos/abate, malathion, cypermethrin, lambda siihalothrin, and deltamethrin) on mosquitoes vector causes resistance, bioactive characteristics which are harmful for the environment, toxic substances, in the insecticides will have adverse impact on human health. Plant-based insecticides become an alternative to control mosquitoes using more environmentally friendly plants to suppress the use of synthetic insecticides and anticipate negative impacts on health [8].

In Indonesia, there are around 2.400 species of plants potential for bioinsecticides [9]. One of the local plants and abundant in South Kalimantan and contains active compounds to be used for bioinsecticides 
against $A$. aegypti is Citrus amblycarpa. The plants contain several active secondary metabolites such as flavonoids, tannins, saponins, and alkaloids [10]. The extracted fresh peel of $C$. amblycarpa is proven to be lethal for $A$. aegypti third larval instars within $7 \mathrm{~h}$ in all concentrations [11]. The aim of the study was to identify and analyze chemical components of C. amblycarpa and its potential as bioinsecticides against $A$. aegypti.

\section{Materials and Methods}

The study was an experimental laboratory conducted in the Laboratory of Entomology and Protozoology, Department of Parasitology, Faculty of Veterinary, Airlangga University. Extraction, isolation, and analysis of chemical compounds were carried out in the Laboratory of Faculty of veterinary, Airlangga University. Around $2.5 \mathrm{~kg}$ fresh samples of Limau Kuit leaves were collected from Kaliukan Village, Astambul, Banjar Regency, and South Kalimantan. Several materials used for extraction, isolation, and identification were ethyl-alcohol p.a. (E. Merck), technical ethanol, and aquadest. A set of maceration, rotary evaporator, pipette, test tube, evaporating dish, analytical balance, vial bottle, micropipette, falcon tube, Erlenmeyer glass, capillary pipe, drop plate porcelain, UV lighting $(\lambda=245 \mathrm{~nm})$, chromatography chamber, thin-layer chromatography (TLC), chromatography column, test pipette heater, electrical stove, $20 \mathrm{~W}$ fluorescent bulb, and a set of gas chromatography-mass spectrometry (GC-MS).

The samples of $C$. amblycarpa leaves were sorted and cleaned by washing the leaves using clean water, drained and distributed on the paper to reduce the water content. After that, $2.5 \mathrm{~kg}$ of samples were dried weight, aired for 7 days by putting the samples in the shade places. The samples were then mashed to generate powder. $1 \mathrm{~kg}$ of simplisia was macerated using ethyl alcohol solvent for 3 days. Filtration was conducted every day and the filtrates were collected and steamed using rotary evaporator to generate $52 \mathrm{~g}$ extracted dry leaves of C. amblycarpa. Phytochemical screening of extract ethyl alcohol and the most active fractions include alkaloids, flavonoids, saponins, phenolics, triterpenoids, quinones, and terpenoids and steroids. TLC analysis on the collected extract was run with mobile phase, a combination of ethyl alcohol p.a with various comparisons, and silent phase used silica gel of 60 GF25. The composition of the best TLC was then employed as a mobile phase in collected extract of chromatography column. Silent phase in the chromatography column was $60 \mathrm{G}$ silica gel. Extract of Limau Kuit leaves and fractions of chromatography column were tested for their activities using BSLT method. The solution making for activity tests was carried out with 3 times replications.

Fraction $\mathrm{LC}_{50}$ was used because it was the most active fraction. The fraction was then analyzed its components using Agilent 6980N Network GC system, detector Agilent 5973 inert MSD. Around $1 \mu \mathrm{L}$ sample was injected to GC-MS operated using glass column for 30 $\mathrm{m}$, diameter of $0.25 \mathrm{~mm}$, and thickness of $0.25 \mu \mathrm{m}$. Oven temperature was $50^{\circ} \mathrm{C}(5 \mathrm{~min}), 10^{\circ} \mathrm{C} / \mathrm{min}$, and $280^{\circ} \mathrm{C}(15$ $\mathrm{min})$. Flow in the column was $1 \mathrm{ml} / \mathrm{min}$ (constant), Wiley Reference of version 7.0. The method was employed to identify a compound, either one or mixed components [12]. Precise spectrometry mass was employed to determine fragmentation and molecules and also to identify components contained in small amounts [13].

\section{Results}

Screening of phytochemical of C. amblycarpa results of the study showed that there were some compounds of secondary metabolites such as free terpenoid/steroid, flavonoid, polyphenol, and saponin. The identification result of chemical compounds of $C$. amblycarpa leaves is presented in Table 1 and Figure 1.

Table 1 shows positive test result in free terpenoids/steroids, flavonoids, polyphenols, and saponins but shows negative test in alkaloids.

\section{Analysis of GC-MS of C. amblycarpa leaves extracted using ethanol}

The samples were analyzed using GC-MS Agilent 6980 N Network GC System, detector Agilent 5973 inert MSD. Chromatogram of C. amblycarpa leaves is presented in Figure 2, while the chemical components are shown in Table 2.

Table 2 shows that there are ten main components offraction obtained from GC-MS analysis. The components are Maragenin (18.82\%), 1,3-benzenedicarboxamide (12.28\%), 2,3,8-trioxocephalotaxane (10.39\%), aristolone, 2H-cyclopropa[a] naphtalen-2-one, noruns-12ene $(7.46 \%)$, palmitic acid, n-hexadecanoic acid $(7.21 \%)$,

Table 1: Screening of phytochemical of Citrus amblycarpa leaves extracted using ethanol

\begin{tabular}{lll}
\hline Phytochemical test & Reagent & Staining appearance \\
\hline Alkaloids & Dragendorf & Orange \\
Free Terpenoids/Steroids & Sulfate acid anisaldehyde & Red purple or purple \\
Flavonoids & Ammonia evaporation & Intensive yellow \\
Polyphenols & $2 \% \mathrm{FeCl}_{3}$ & Brown to black \\
Saponins & a drop of $2 \mathrm{~N} \mathrm{HCl}$ & Stabile foam for more than 30 min \\
\hline$+:$ Contain chemical compound, $-:$ No chemical compound & & + \\
\hline
\end{tabular}




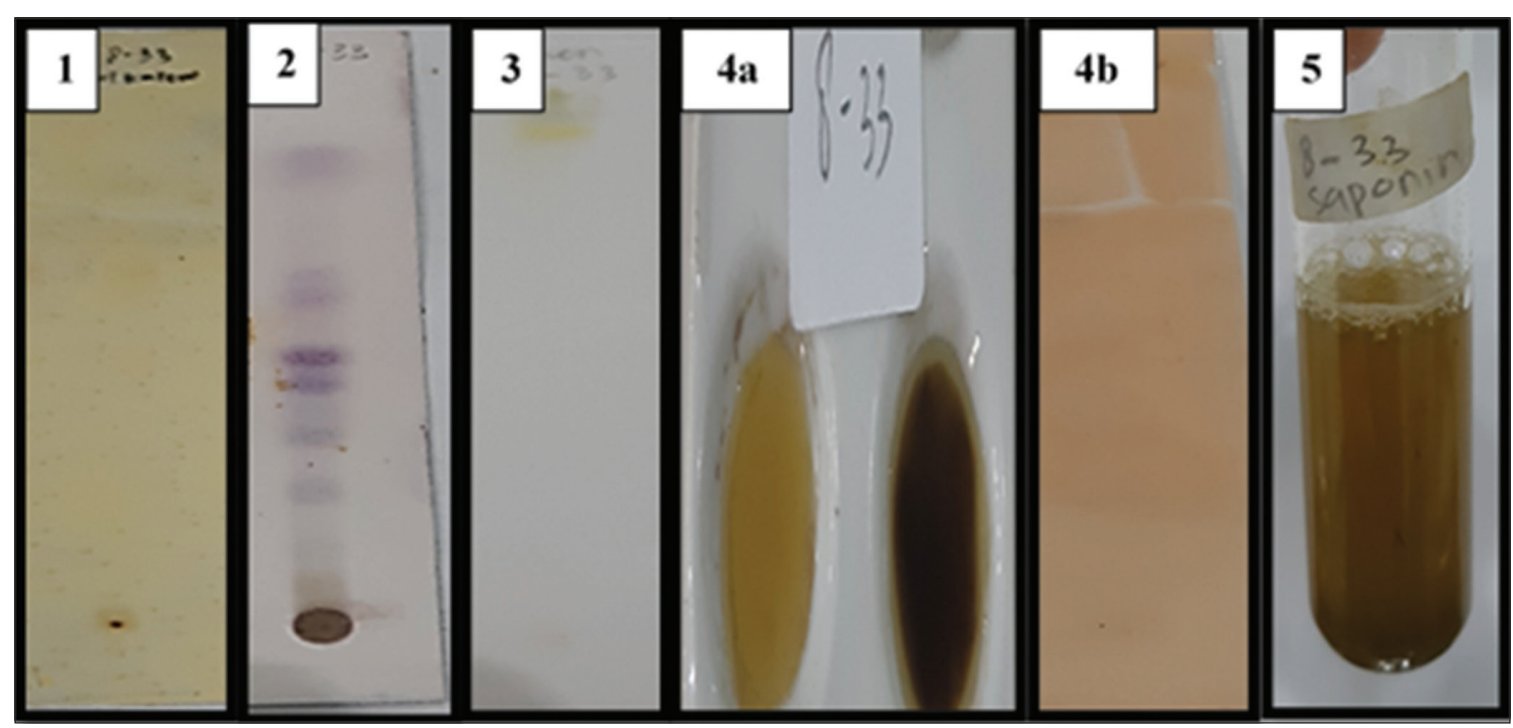

Figure 1: (1) Samples do not show orange spot (contain negative [-] alkaloids), (2) purple spot (contain positive (+) terpenoids/free steroids) (3) intensive yellow spot (contain positive (+) flavonoids), (4a) based on Ferric chloride test, samples display black-blue green spot (contain positive (+) polyphenols), (4b) based on KLT test, samples show blackish spot (contain positive (+) polyphenols), and (5) based on foam test, the foam can last for 30 min (contain positive (+) saponins)

stigmasterol, demecolcine $(7.03 \%)$, alpha-tocopherol (5.88\%), 2,4,5-trimethylphenol, pseudocumenol (4.21\%), germacrene-D (3.45\%), and 9-octadecenoic acid $(3.36 \%)$.

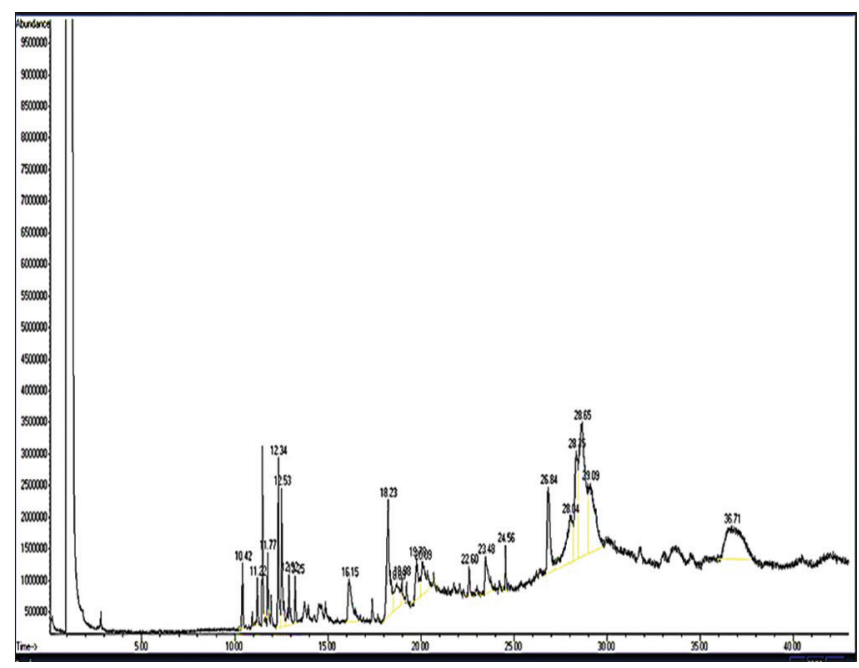

Figure 2: Chromatogram of Limau Kuit (Citrus amblycarpa) leaves extracted using ethanol, analyzed using gas chromatography-mass spectrometry

\section{Discussion}

Indonesia possesses a wide variety of local plants potential for biopesticidal [14]. In the present study, we are interested in C. amblycarpa because the plant is a local orange and abundant from South Kalimantan. Moreover, it could also be plant-based insecticides. The plant contains secondary metabolite compounds such as alkaloids, saponins, tannins, and flavonoids [10]. Principally, plant cells contain primary and secondary metabolites. Primary metabolites are carbohydrate, amino acids, lipids, and vitamins, while secondary metabolites are a source for pharmaceuticals, food additives, perfume ingredients, or pesticides [15]. The secondary metabolite compounds are a relatively safe insecticidal to environment and human health because it possesses insufficient risks [16].

The purpose of the study was to identify and analyses the chemical content of $C$. amblycarpa leaves using TLC and GC-MS analysis, and also to examine its potency as bioinsecticidal. The active compounds such as alkaloids, terpenoids, flavonoids, and polyphenols in the extract were determined using color reagent, while saponins compounds were tested by foam test. The results showed that extract ethanol of the leaves showed positive test on terpenoids/steroids, flavonoids, polyphenols, and saponins compounds, but showed negative result on alkaloids compounds (Table 1). Ghosh reported that steroids, sitosterols, and stigmasterols compounds are found in maja leaves and possess larvicidal activity for $A$. aegypti, A. stephensi and $C$. quinquefasciatus larvae [17]. Steroids are toxic to nerve cells affecting neurotransmission function and inhibiting ion transports making mosquitoes limp and death [18].

Flavonoids contained in the plant affects the respiration of mosquitoes. The compound gets into the nerve cells along with the air through respiratory organs decreasing the amount of oxygen. As a result, the mosquitoes suffer from nervous and spiracle disruptions and then death [19]. Plants containing flavonoids compounds have toxic effect on Anopheles and $A$. aegypti larvae, indicated by the loss of chitin layer and abnormal body stretching [20].

The results of chromatogram and analysis of GC-MS extract ethanol of C. amblycarpa leaves showed 22 compounds with ten primary components of 
Table 2: Chemical components of Citrus amblycarpa leaves extracted using ethanol and analyzed using GC-MS

\begin{tabular}{|c|c|c|c|c|c|c|}
\hline \multirow[t]{2}{*}{ Peak } & \multirow{2}{*}{$\begin{array}{c}\text { Retention time (min) } \\
10.42\end{array}$} & \multirow{2}{*}{$\begin{array}{c}\text { Area }(\%) \\
1.46\end{array}$} & \multirow{2}{*}{$\begin{array}{l}\text { Chemical } \\
\text { formula } \\
\mathrm{C}_{10} \mathrm{H}_{16}\end{array}$} & \multirow{2}{*}{$\begin{array}{l}\text { Compound name } \\
\text { Alpha-terpinene }\end{array}$} & \multirow{2}{*}{$\begin{array}{l}\text { Biological activities } \\
\text { Potential larvicides and mosquito Repellent }{ }^{14}\end{array}$} & Chemical structure \\
\hline & & & & & & \\
\hline 2 & 11.22 & 0.99 & $\mathrm{C}_{15} \mathrm{H}_{24}$ & $\begin{array}{l}\text { 2-Methylene-4,8.8 } \\
\text { trimethyl-4-vinyl-Bicyclo [5.2.0] } \\
\text { nonane, Beta-Elemene }\end{array}$ & Potential Insecticide of Aedes aegypti ${ }^{15}$ & \\
\hline 3 & 11.78 & 0.91 & $\mathrm{C}_{15} \mathrm{H}_{24}$ & Gamma elemene, Germacrene-B & Potential Insecticide of Aedes aegypti ${ }^{15}$ & \\
\hline 4 & 12.34 & 3.45 & $\mathrm{C}_{15} \mathrm{H}_{24}$ & Germacrene-D & $\begin{array}{l}\text { Toxic to Anopheles subpictus, Aedes albopictus } \\
\text { and Culex tritaeniorhynchus larvae }{ }^{16} \text {, Potential } \\
\text { insecticides }{ }^{17}\end{array}$ & \\
\hline 5 & 12.53 & 3.13 & $\mathrm{C}_{15} \mathrm{H}_{24}$ & Lepidozene & Mosquito Repellent Aedes aegypti ${ }^{18}$ & \\
\hline 6 & 12.92 & 1.66 & $\mathrm{C}_{15} \mathrm{H}_{24}$ & Delta-cadinene, beta.-cadinene & Potential insecticides ${ }^{19}$, Anti feedant ${ }^{20}$ & \\
\hline 7 & 13.25 & 0.91 & $\mathrm{C}_{15} \mathrm{H}_{24}$ & Alpha-Gurjunene,. beta.-Neoclovene & $\begin{array}{l}\text { Activity of larvicides of Aedes aegypti } i^{21} \text {, mosquito } \\
\text { repellent }^{22}\end{array}$ & \\
\hline 8 & 16.16 & 4.21 & $\mathrm{C}_{9} \mathrm{H}_{12} \mathrm{O}$ & $\begin{array}{l}\text { 4-Hydrazinopyrazino [3,2-D] } \\
\text { Pyrimidine,-2,4,5 Trimethylphenol, } \\
\text { Pseudocumenol }\end{array}$ & Potential insecticides ${ }^{23}$ & \\
\hline $\begin{array}{l}9 \\
10\end{array}$ & $\begin{array}{l}18.23 \\
18.70\end{array}$ & $\begin{array}{l}7.21 \\
2.95\end{array}$ & $\mathrm{C}_{16} \mathrm{H}_{32} \mathrm{O}_{2}$ & $\begin{array}{l}\text { Palmitic acid, n-Hexadecanoic acid } \\
\text { Palmitic acid, n-Hexadecanoic acid }\end{array}$ & $\begin{array}{l}\text { Possess biolarvicides effect on Aedes aegypti, } \\
\text { Culex sp., and Anopheles sundaicus larvae. }{ }^{24} \\
\text { Activity of insecticides on Aedes aegypti. }{ }^{25}\end{array}$ & \\
\hline 11 & 18.98 & 0.81 & $\mathrm{C}_{18} \mathrm{H}_{34} \mathrm{O}_{2}$ & 9-Octadecenoic acid & Lethal to Aedes aegypti and Culex pipiens & \\
\hline 12 & 19.78 & 2.65 & & 9-Octadecenoic acid & pallens larva $e^{26}$ & \\
\hline 13 & 20.09 & 3.36 & & 9-Octadecenoic acid & & \\
\hline 14 & 22.60 & 0.77 & $\mathrm{C}_{34} \mathrm{H}_{58} \mathrm{O}_{4}$ & $\begin{array}{l}\text { Dioctyl ester, } 1-2 \\
\text { Benzenedicarboxylic acid }\end{array}$ & Activity of larvicides vector of Aedes aegypti ${ }^{27}$ & \\
\hline 15 & 23.48 & 2.87 & $\mathrm{C}_{9} \mathrm{H}_{9} \mathrm{NO}$ & Cinnamamide & $\begin{array}{l}\text { Potential insecticides and antifungal, }{ }^{28} \\
\text { Repellent }^{29}\end{array}$ & \\
\hline 16 & 24.56 & 0.80 & $\mathrm{C}_{15} \mathrm{H}_{28} \mathrm{O}$ & Dihydrofarnesol,-dodecatrienol & Antioxidant, antifungal, antibacteria $\left.\right|^{30}$ & \\
\hline 17 & 26.84 & 5.88 & $\mathrm{C}_{29} \mathrm{H}_{50} \mathrm{O}_{2}$ & Alpha-tocopherol, Vitamin E & Antioksidant ${ }^{31}$ & \\
\hline 18 & 28.04 & 7.03 & $\mathrm{C}_{29} \mathrm{H}_{48} \mathrm{O}$ & Stigmasterol, Demecolcine & Potential Insecticides ${ }^{32,33}$ & \\
\hline 19 & 28.35 & 7.46 & $\mathrm{C}_{15} \mathrm{H}_{22} \mathrm{O}$ & $\begin{array}{l}\text { Aristolone, } 2 \mathrm{H} \text {-Cyclopropa[a] } \\
\text { naphtalen-2-one, Noruns-12-ene }\end{array}$ & Potential Insecticides ${ }^{34}$ & \\
\hline
\end{tabular}


Table 2: (Continued)

\begin{tabular}{lcccccc}
\hline Peak & Retention time (min) & Area (\%) & $\begin{array}{l}\text { Chemical } \\
\text { formula }\end{array}$ & Compound name & Biological activities \\
\hline 20 & 28.65 & 18.82 & $\mathrm{C}_{29} \mathrm{H}_{46} \mathrm{O}_{2}$ & Maragenin I & \\
21 & 10.39 & $\mathrm{C}_{20} \mathrm{H}_{36}$ &
\end{tabular}

the fraction. Maragenin I is a main compound with the highest component found in the leaves. Maragenin I is a derivate of triterpenoid [21]. Literature study has been done, Maragenin I compound is found to be antiviral [22], anti-microbe, and antioxidant [23]. The compound is able to control the growth of insects and potential as insecticides [24]. It is a derivative of triterpenoid/steroid. Therefore, it is concluded that the compound is potent to be used as biopesticides, and poisonous to $A$. aegypti.

The compound is able to kill $A$. aegypti to $90 \%$. Stigmasterol is the main sterol of plasma membrane in the cell of plants [25]. Sterols, in plants known as phytosterol and belongs to the group of alcohol steroids, are natural phytochemical exclusively found in plants. The compound is alcohol soluble. Stigmasterols are present in various medical plants and it has been reported that the compounds inhibit the activity of acetyl cholinesterase making them possessing larvicidal effect. Moreover, stigmasterols are one of active compounds which contribute to insecticidal [26]. It is potential to prevent insects and to be developed for botanical biopesticides.

D-alpha-tocopherol (Vitamin E) is fat-soluble compound and the main antioxidant for cells. This compound contains highest antioxidant activity of all tocopherols [27]. Trimethylphenol compound is found in the extract of Artemia salina flowers with cytotoxic that can be used for pesticides. Germacrene-D is a compound belonging to sesku terpenoid hydrocarbon group [28]. This compound has been reported poisonous to Anopheles subpictus, Aedes albopictus, and Culex tritaeniorhynchus larvae. Germacrene-D compound causes typical biological activities such as toxic which inhibits food, antiparasitic, and pesticides.

9-Octadecenoic acid, also known as oleat acid, is a compound from fatty acid. Compounds from lipid acids are benefit to prevent pests. The acid can be lethal to $A$. aegypti and Culex pipiens pallens larvae. 9-Octadecenoic acid is also an active principle compound obtained from the extract of Annona glabra. It is also poisonous that work quickly if applied manually and serves as ingested and contact insecticides. Thus, it affects mortality rate for Eurema sp. larvae [29], [30], [31], [32].

\section{Conclusion}

C. amblycarpa leaves contain active chemicals suchasfreeterpenoids/steroids, flavonoids, poliyphenols, and saponins potential as bioinsecticides. The analysis of GC-MS showed that the main components of fraction were maragenin I, 1,3-benzenedicarboxamide, 2,3,8-trioxocephalotaxane, aristolone, $2 \mathrm{H}$-cyclopropa[a] naphtalen-2-one, noruns-12-ene, palmitic acid, n-hexadecanoic acid, stigmasterol, demecolcine, alphatocopherol, 2,4,5-trimethylphenol, pseudocumenol, and germacrene-D. The active compounds of the leaves could be an alternative to control mosquitoes in the future by replacing the use of resistant temephos.

\section{Acknowledgments}

The authors would like to express the gratitude to Directorate General of Research and Community Service, Directorate General of Research Strengthening and Development, Ministry of Research, Technology and Education for their financial support during the study. The authors would also like to thank to the director of LPPM University of Islam Kalimantan, and the head department of Parasitology in the Faculty of Veterinary Medicine Airlangga University, Jawa Timur 60115, Indonesia.

\section{References}

1. Tosepu R, Tantrakarnapa K, Nakhapakorn K, Worakhunpiset S. Climate variability and dengue hemorrhagic fever in Southeast Sulawesi Province, Indonesia. Environ Sci Pollut Res Int. 2018;25(15):14944-52. https://doi.org/10.1007/ s11356-018-1528-y

PMid:29549613

2. Mapalagamage M, Handunnetti S, Premawansa G, Thillainathan S, Fernando T, Kanapathippillai K, et al. Is total 
serum nitrite and nitrate (NOx) level in dengue patients a potential prognostic marker of dengue hemorrhagic fever? Dis Markers. 2018;2(2):1-9. https://doi.org/10.1155/2018/5328681 PMid:30069272

3. Retnaningrum OT, Martini $M$, Raharjo $M$. Incidence of dengue hemorrhagic fever (DHF) in semarang coastal area: Epidemiology descriptive case and bionomic vector. Indones $\mathrm{J}$ Trop Infect Dis. 2019;7(6):144-9. https://doi.org/10.20473/ijtid. v7i6.10389

4. Harapan H, Michie A, Mudatsir M, Sasmono RT, Imrie A. Epidemiology of dengue hemorrhagic fever in Indonesia: Analysis of five decades data from the National Disease Surveillance. BMC Res Notes. 2019;12:350. https://doi. org/10.1186/s13104-019-4379-9

\section{PMid:31221186}

5. Ishak NI, Kasman K. The effect of climate factors for dengue hemorrhagic fever in Banjarmasin city, South Kalimantan Province, Indonesia, 2012-2016. Public Health Indones. 2018;4(3):121-8. https://doi.org/10.36685/phi.v4i3.181

6. Ridha MR, Sembiring W, Fadilly SS. Indikator Entomologi dan Status Resistensi Vektor Demam Berdarah Dengue (Aedes aegypti L) Terhadap Beberapa Golongan Insektisida di Kota Banjarbaru. In: Prosiding Seminar Nasional Seri No. 8; 2018. p. 128-42. https://doi.org/10.22435/vektorp.v13i2.931

7. Susilowati RP, Darmanto W, Aminah NS. "MORIZENA" against Aedes aegypti death. Indones J Trop Infect Dis. 2018;7(2):50-5.

8. Hastutiek AS, Heru PR. Permot (Passiflora foetida Linn.) leaf extracts as bioinsecticide against Aedes aegypti larvae. Southeast Asian J Trop Med Public Health. 2017;48(6):1169-74.

9. Anwar C, Syukur KM, Dalilah D, Salni S, Novrikasari N. The efficacy of red ginger fraction (Zingiber officinale Roscoe var. rubrum) as insecticidal Aedes aegypti. Biosci Med. 2018;2(2):3141. https://doi.org/10.32539/bsm.v2i2.40

10. Irwan A, Mustikasari K, Ariyani D. Chemical preliminary evaluation of leaves, peels, and fleshs fruit of limau kuit: local orange of south kalimantan. Sains Terap Kim. 2017;11(2):71-9. https://doi.org/10.20527/jstk.v11i2.4040

11. Ishak NI, Kasman K, Chandra C. Effectiveness of Lime Skin Extract (Citrus amblycarpa) as natural larvacide aedes aegypti instar III. J MKMI. 2019;15(3):302-10. https://doi.org/10.30597/ mkmi.v15i3.6533

12. Sastrohamidjojo H. Kromatografi. Yogyakarta: Liberty Yogyakarta; 1985.

13. Harborne J. Metode Fitokimia Penuntun Cara Modern Menganalisis Tumbuhan. Bandung: Penerbit ITB; 1987.

14. Astriani Y., Widawati $M$. Potential plant in indonesia as natural larvicides for aedes aegypti. SPIRAKEL. 2018;8(1):37-46. https://doi.org/10.22435/spirakel.v8i2.6166.37-46

15. Kartina, Agang MW, Adiwena M. Characterisation of phytochemical content of leaf extract from karamunting (Melastoma malabatchricum L.) using gas chromatography mass spectrometry (GC-MS). Biota. 2019;4(1):16-23. https:// doi.org/10.24002/biota.v4i1.2363

16. Perumalsamy H, Jang MJ, Kim J, Kadarkarai M, Ahn Y. Larvicidal activity and possible mode of action of four flavonoids and two fatty acids identified in Millettia pinnata seed toward three mosquito species. Parasit Vectors Biomed Cent. 2015;8:237. https://doi.org/10.1186/s13071-015-0848-8

PMid:25928224

17. Ghosh A. Efficacy of phytosterol as mosquito larvicide. Asian
Pacific J Trop Dis. 2013;3(3):252. https://doi.org/10.1016/ s2222-1808(13)60050-x

18. Hidana SN. Effectiveness of lemongrass leaves (Cymbopogon nardus) extract as anti-oviposition to aedes aegypti mosquito. J Kesehat Bakti Tunas Husada. 2015;13(1):130-4. https://doi. org/10.36465/jkbth.v13i1.24

19. Utami IW, Cahyati WA. Potential of cambodia leaf extract (Plumeria acuminata) as insecticide against aedes aegypti mosquitoes. HIGEIA. 2017;1(1):22-8.

20. Gautam K, Kumar P, Poonia S. Larvicidal activity and GC-MS analysis of flavonoids of Vitex negundo and Andrographis paniculata against two vector mosquitoes Anopheles stephensi and Aedes aegypti. J Vector Borne Dis. 2013;50(3):171-8. PMid:24220075

21. Hylands PJ, Salama AM. Maragenin I, II, and III, new pentacyclic triteroenes from Marah macrocarpus. Tetrahedron. 1978;35:417-20. https://doi.org/10.1016/0040-4020(79)80081-2

22. Itokawa $H, N a k a j i m a ~ H, ~ I k u t a A$, litaka $Y$. Two triterpenes from the flowers of Camellia japonica. Phytochemistry. 1981;20(11):253942. https://doi.org/10.1016/0031-9422(81)83089-0

23. Aref HL, Aouni M, Chaumon JP, Said K, Fekih A, Génétique L De. In vitro antiviral activities of Jrani caprifig latex and its related terpenes. Afr J Microbiol Res. 2011;5(32):5812-8. https://doi. org/10.5897/ajmr10.104

24. El-tantawy ME, Haggag EG, Kamal AM, Lithy RM. Phytochemical and biological evaluation of banana, cantaloupe and guava waste parts. J Pharm Res. 2016;10(5):308-18.

25. Aboobucker SI, Suza WP. Why do plants convert sitostero to stigmasterol ? Front Plant Sci. 2019;10:354. https://doi. org/10.3389/fpls.2019.00354 PMid:30984220

26. Okonkwo CO, Onyeji CM. Insecticidal potentials and chemical composition of essential oils from the leaves of Phyllanthus amarus and Stachytarpheta cayennensis in Nigeria. Int J Biochem Res Rev. 2018;22(3):1-16. https://doi.org/10.9734/ ijbcrr/2018/42315

27. Ifeanyi OE. A review on palm oil supplemented diet and enzymatic antioxidants in aging. Int $\mathrm{J}$ Curr Res Med Sci. 2018;4(4):43-52.

28. Wartono MW, Ainurofiq MI. Chemical contituent of the essential oils from the fruits of Piper betle L, Piper cubeba L, and Piper retrofractum Vahl. Molekul. 2014;9(1):1-12. https://doi. org/10.20884/1.jm.2014.9.1.143

29. Ishak H, Mallongi A, Wahid I, Bachtiar I. Spatiotemporal factors related to dengue hemorrhagic fever in Makassar city, 20102014. Indian J Public Health Res Dev. 2018;9(6):452. https:// doi.org/10.5958/0976-5506.2018.00596.x

30. Muhith A, Winarti E, Perdana SS, Haryuni S, Rahayu KI, Mallongi A. Internal locus of control as a driving factor of early detaction behavior of servical cancer by inspection visual of acetic acid method. Open Access Maced J Med Sci. 2020;8(E):113-6. https://doi.org/10.3889/oamjms.2020.4341

31. Mallongi A, Birawida AB, Astuti RD, Saleh M. Effect of lead and cadmium to blood pressure on communities along coastal areas of Makassar, Indonesia. Enferm Clín. 2020;30(4):313-7. https:// doi.org/10.1016/j.enfcli.2020.03.001

32. Darmawan UW, Ismanto A. Mortality of yellow butterfly (Eurema sp.) larvae due to pond apple (Annona glabra L.) seed extract application. J Penelit Hutan Tanam. 2016;13(2):157-64. https:// doi.org/10.20886/jpht.2016.13.2.157-164 